Психолого-педагогічні проблеми становлення сучасного фахівця Випуск 2018

УДК 172.15(37+608:658.3)-043.83:614.253.4

DOI 10.26697/9786177089017.2018.191

(С Ісакова О. Л., Коваленко Г. Г., 2018

Ісакова Оксана Людвігівна

Вінницький медичний коледж ім. акад. Д. К. Заболотного

Коваленко Галина Григорівна

Вінницький медичний коледж ім. акад. Д. К. Заболотного

\title{
ПАТРІОТИЧНЕ ВИХОВАННЯ ЯК ОДИН ІЗ ВАЖЛИВИХ ШЛЯХІВ ФОРМУВАННЯ МАЙБУТНЬОГО МЕДИКА
}

У статті визначено актуальність національно-патріотичного виховання майбутніх медиків у сучасних умовах шляхом формування иіннісного ставлення молодого спеиіаліста з медичною освітою до українського народу, Батьківщини, держави, наиії.

Ключові слова: патріотизм, патріотичне виховання, медики земляки АТО, подвиги героїв-медиків.

«Патріотичне виховання - ие сфера духовного життя, яка проникає в усе, щзо пізнає, робить, до чого прагне, щъо любить $i$ ненавидить людина, яка формусться»

(В. О. Сухомлинський)

Проблема, їі зв'язок із важливими науковими чи практичними завданнями. XXI ст. поставило перед Україною нові випробування. У цей час держава взяла курс на євроінтеграцію й сміливо стала на захист ідеалів демократії, відстоюючи права та свободу людини. Сьогодні наш народ проходить суворе випробування на єдність, мужність, стійкість. Страшні події останніх років засвідчили необхідність виховання в молоді почуття патріотизму, відданості загальнодержавній справі зміцнення країни, активної громадянської позиції. Це, без перебільшення, $є$ питанням національної безпеки.

Текст статті розкриває особливості національно-патріотичного виховання майбутніх медиків в Україні, спрямованого на формування й розвиток таких рис особистості, як готовність до виконання, окрім професійного, громадянського та конституційного обов'язків із захисту національно-державних інтересів, незалежності та цілісності держави, утвердження ії суверенітету тощо.

Ціль статті - обмін досвідом організації патріотичного виховання майбутніх медиків у вищих навчальних закладах України. 
Аналіз публікацій (виділення невирішених проблем). На думку видатного українського педагога В. Сухомлинського, майстерність виховання, полягає в тому, щоб громадянське, патріотичне життя починалося для людини 3 дитячих років. «Ми домагаємося, - писав він, - щоб у дитини і підлітка боліло серце за те, що відбувається навколо неї і поряд 3 нею, щоб вона 3 дитинства пережила, відчула громадянські радощі, громадянські прикрощі» [4, c. 560], «щоб кожен вихованець відчув особисту причетність до долі народу, пройшов урок громадського піклування про інтереси народу, перехворів, перестраждав за те, що особисто його ніби не стосується» $[3$, c. 146$]$.

В. Сухомлинський вважав, що головним завданням патріотичного виховання $€$ формування в молодої людини відчуття синівської відданості рідній землі, де вона народилася й виросла, де відчула себе частиною свого Великого й Мудрого народу, з якого й починається родина, рідний край, Вітчизна. Також відомий педагог сформував такі основні принципи процесу патріотичного виховання: глибокі патріотичні почуття й переконання, моральний ідеал, патріотичні турботи й тривоги за долю свого народу, патріотична непримиренність, патріотична гордість та інші.

Проблема патріотичного виховання також досліджувалася такими класиками педагогічної науки: С. Русовою, Г. Ващенко, О. Огієнко, О. Духновичем, А. Макаренком, Г. Сковородою, К. Ушинським, Я. Чепігою та іншими видатними вченими. Аналіз останніх досліджень публікацій 3 питань патріотичного виховання свідчить, що цю проблему вивчали також А. Афанас'єв, В. Каюков, М. Качур, В. Дроговоз, С. Оришко та інші.

Виклад основного матеріалу, обгрунтування результатів дослідження. Події останніх років, що відбулися в Україні, підняли питання патріотичного виховання на новий рівень. Молодь сьогодні має усвідомити, що несе на собі найбільшу відповідальність за наше спільне майбутнє. Цей аспект виховної роботи у практиці сучасних навчальних закладів представлено нормативними документами.

В Указі Президента України про Стратегію національнопатріотичного виховання дітей та молоді на 2016-2020 роки, формування ціннісних орієнтирів і громадянської самосвідомості у дітей та молоді повинно здійснюватися на прикладах героїчної боротьби українського народу за самовизначення й творення власної держави, ідеалів свободи, соборності та державності, на прикладах мужності та героїзму учасників революційних подій в Україні у 2004 році, у 2013-2014 роках, учасників антитерористичної операції в Донецькій та Луганській областях. 
Вирішуючи поставлене завдання, викладачі Вінницького медичного коледжу вирішили залучити студентів до проектної роботи, спрямованої на дослідження участі медиків-земляків в АТО, а також організувати зустрічі 3 такими людьми, провести виховні години, присвячені вшануванню полеглих білих янголів.

Виконуючи поставлені завдання, студенти зрозуміли, що важко переоцінити роль медиків у зоні АТО на Сході України та під час проведення військових операцій. У медиків на війни свій, окремий, особистий фронт. Їхня зброя не кулемети, а скальпелі; їхнє поле бою операційна. I перемога в них особлива - перемога над смертю. За час перебування в зоні АТО багатофункціонального мобільного шпиталю Військово-медичного клінічного центру Центрального регіону більше тисячі військовослужбовців 3 вогнепальними, мінно-розривними та осколковими пораненнями отримали професійну медичну допомогу. Хірурги зробили безліч операцій різного ступеня складності. У польових умовах працюють лікарі вищої та першої категорії, серед яких спеціалісти з вченими ступенями. Медик - це мирна професія, але, коли починається війна, медичні працівники одні 3 перших опиняються на фронті. Тому там по-новому починає звучати їх професія. Клятва Гіппократа спонукає людей в білих халатах переборювати всі емоції й особисті негаразди, для того, щоб завжди бути в перших рядах і з честю виконати свій професійний обов'язок порятунок людського життя. Яскравим прикладом відданості своїй професії для студентів стала віднайдена нами інформація про колишнього випускника Вінницького медичного коледжу імені акад. Д. К. Заболотного, а сьогодні головного військового хірурга, генерала-майора медичної служби Збройних сил України, кандидата медичних наук, директора Військово-медичного департаменту Міноборони, Заслуженого лікаря України Андрія В'ячеславовича Вербу. У липні 2014 року він провів першу в історії України складну операцію в польових умовах - врятував від важкого поранення розвідника, який дивом дістався до медиків. Тисячі бійців на рахунку цього лікаря. При цьому жодного пораненого бійця, який потрапив у руки Андрія Верби, не було втрачено. Студенти захоплюються мужністю та кваліфікацією лікаря. Слова хірурга: «Нам головне зберегти генофонд. А території ми відвоюємо. Не сьогодні, так завтра» - стали життєвим орієнтиром майбутніх медиків.

Великий виховний вплив на студентів коледжу мала зустріч із колишніми випускниками Вінницького медичного коледжу Денесюком В. Б., підполковником, начальником відділу медичного постачання Центрального регіону та Пасіковим Д. О., майором, старшим офіцером відділу медичного постачання Центрального регіону, які неодноразово перебували на передовій. 
Висновки. Знайомство студентів із життям лікарів, учасників ATO, обговорення їхній діяльності на передовій $є$ однім із шляхів формування ціннісних орієнтирів і громадянської самосвідомості в молоді. Подвиги героїв-медиків є прикладом мужності, порядності, відповідальності, справжнього патріотизму для всіх прийдешніх поколінь. Студенти розуміють, що бути медиком у країні, де ллється кров найкращих іiї синів, - означає бути готовим на подвиг. Майбутні медики розуміють, що від їх готовності щодня працювати, не покладаючи рук, залежить не тільки життя людей, й становлення нашої держави. Патріот не залишається байдужим до своїх обов'язків, не збагачується нечесним шляхом, бо все це завдає шкоди його Батьківщині. За висловом І. Франка, «наш голосний, фразеологічний та більшій мірі нещирій, бо ділами не потертий патріотизм, мусить уступити місце поважному, мовчазному, але глибоко відчутому народолюбству, що виявляє себе не словами, а працею».

\section{Література}

1. Стратегія національно-патріотичного виховання дітей та молоді на 2016-2020 роки. Указ Президента України 13.10.2015 p. №580/2015 [Електронний ресурс] - Режим доступу: http://osvita.ua/legislation/pozashk_osv/48106/print/.

2. Про затвердження Концепції національно-патріотичного виховання дітей і молоді. Наказ МОН України № 641 від 16 червня 2015 року [Електронний ресурс] - Режим доступу: http: //osvita.ua/legislation/Ser_osv/47154/.

3. Сухомлинський В. О. Народження громадянина / В. О. Сухомлинський // Вибр. твори: В 5-ти. - К. : Рад. школа, 1997. T. 3. $-670 \mathrm{c}$.

4. Сухомлинський В. О. Проблеми виховання всебічно розвиненої особистості // Вибр. твори : в 5-ти томах. - Т. 1. - К. : Рад. школа, 1977. - 653 с.

Оксана Исакова, Галина Коваленко. Патриотическое воспитание как один из важных путей формирования будущего медика.

В статье определена актуальность национально-патриотического воспитания будущих медиков в современных условиях путем формирования ценностного отношения молодого специилиста $c$ медицинским образованием к украинскому народу, Родине, государству, начии.

Ключевые слова: патриотизм, патриотическое воспитание, медики земляки АТО, подвиги героев-медиков. 
Психолого-педагогічні проблеми становлення сучасного фахівця Випуск 2018

Oksana Isakova, Galyna Kovalenko. Patriotic education as one of the important ways of forming the future physician.

The article touches upon the issue of urgency of national-patriotic education of future medical workers in modern society by forming a valuable attitude of a young specialist with medical education to the Ukrainian people, the Motherland, the state, and the nation.

Keywords: patriotism, patriotic upbringing, physicians - countrymen of ATO, achievements of doctors-heroes.

Стаття надійшла до редакційної колегії 03.05.2018 Прийнято до друку 08.05.2018

\section{Інформація про авторів:}

Ісакова Оксана Людвігівна - спеціаліст вищої категорії, викладач математики, Вінницький медичний коледж імені академіка Д. К. Заболотного.

Коваленко Галина Григорівна - спеціаліст вищої категорії, викладач-методист, викладач української мови та літератури, Вінницький медичний коледж імені академіка Д. К. Заболотного. 